\title{
A tudós Kaán Károly, az Alföld „komplex regionális" fejlesztésének egyik nagy formátumú előfutára
}

\section{The scholar Károly Kaán, one of the significant precursors of the 'complex regional' development of the Great Hungarian Plain}

\author{
CSATÁRI BÁLINT
}

„Szeressétek egymást, mint ahogy én

Titeket és a magyar erdöt szerettem." 1

\section{Bevezető gondolatok}

Válságos korszakokban - ha időlegesen is, de - mindig a magyar közgondolkodás homlokterébe került az Alföld. A reformkor Legnagyobb Magyarja², Gróf Széchenyi István fö müveinek szinte mindegyikében szót ejt róla (Eszmetöredékek különösen a Tisza völgy rendezését illetően, Javaslat a magyar közlekedésügy rendezéséről, Stádium, A selyemrül stb.), s a Tisza szabályozásának és a vasútügynek a felkarolásával valóban döntő befolyással volt munkálkodása erre a természeti környezetét tekintve homogén, csaknem egységes magyar nagytájra, régióra. Amelynek Szabó Zoltán Szerelmes földrajza szerint ismerjük a születésnapját is. Az a nap, mikor Petőfi Sándor 1844-ben publikálta a Honderüben „Az Alföld” c. költeményét. Ebben a jeles pillanatban a költő ezt a tájat a magyar szabadság jelképévé is felmagasztosította. A magyar közismeret és közgondolkodás tekintetében tehát különös táji szimbólummá is vált ezáltal.

A kiegyezést követően, leginkább „Szeged árvízi mártíromsága” ${ }^{3}$ után, Tisza Kálmán vagy éppen Kemény Zsigmond értekezik róla. Utóbbi „a hagyománytalan Alföldről” beszél, különösen Erdéllyel összevetve. Később, többek között Klebelsberg Kuno által is gyakran idézve valóságos „Kemény szállóigévé” vált a következő Alföld-minősítő mondat: „A Duna és Tisza tere Ma-

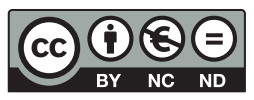


gyarország szíve és a magyar faj fészke. Ami ott sikertelen, az a más részeken erőre kapni s a hazára nagy befolyást gyakorolni nem fog." ${ }^{4}$ Valóban? Mi lehet a véleményünk ma, 2012-ben erről az állításról? Azóta is - mondhatni folyamatosan - aktuálisnak tekinthetjük ezt a mondatot? Kaán Károly munkásságának alaposabb tanulmányozása egyértelműen arra mutat, hogy ő továbbvitte ennek a súlyos mondatnak az „akkori”, XX. század elejei aktualitásait saját alkotásaiban.

Hiszen Trianon után - nyilvánvalóan - még inkább felszínre kerültek a lényegesen fejlettebb magyar régiók - Partium, Erdély, Felvidék - felé addig „csak szinte tranzitterületként” számba vett Alföld problémái. Néhány paraszt-polgár mezővárosi szigetet kivéve egyértelműen elmaradott volt ez a vidék, s e nagytájunk súlyos agrártermelési, túlnépesedési és mindezek következtében megélhetési gondjai egyre nyilvánvalóbbá váltak. Klebelsberg Kuno kultuszminiszter tehát nem véletlenül tette e régiót egyetem- és iskolalapító programjának - mai kifejezéssel élve - fejlesztési kulcsterületévé. Kaán és Klebelsberg kortársak voltak, bár egymást viszonylag keveset idézték.

Kaán Alföldet érintő munkásságában a Széchenyi István által egykor javasolt további vízrendezések elmaradása, a "mammut-falvak ${ }^{5}$ " és a "tanyavilág", a közlekedés fejletlensége, az erdők, fasorok hiánya, az írástudatlanság, a megújuló mezőgazdasági termeléshez (a „Hollandiává váláshoz”) szükséges tudás hiánya, mind-mind felmerült valamilyen - mai szóhasználattal élve - regionálisnak tekinthető és ekkora léptékű területi szinten értelmezhető megoldásokat igénylő táji-térségi-gazdasági-társadalmi problémaként.

Az ország jelentős területének elvesztése utáni különös és fontos történelmi időszaknak lett az Alföld régió fentebb sorolt megoldandó ügyeit felkaroló, azokon rendkívül sokféle és igen színvonalas fejlesztési javaslattal segíteni szándékozó, kiemelkedő és eredeti gondolatokat megfogalmazó alkotója, köztisztviselője, értelmiségi személyisége, miniszteriális államférfiúja Kaán Károly. Műveinek mai aktualitása - egy sokak szerint több vonatkozásban sikertelen, de kétségtelenül rendkívül nagy (ismét csak történelmi jelentőségü) - gazdasági-társadalmi rendszerváltozás utáni korszakban, a XXI. század első évtizedének végén szinte megdöbbenti az olvasót. Ezekből az aktualitásokból kísérel meg néhányat feleleveníteni - a hálás utókort szolgálva - e kis tanulmány.

\section{Kaán Károly, a felelős köztisztviselö és gondolkodó8}

Kaán Károly (1. ábra) az akadémiai és a magyar életrajzi lexikon szerint 1867. július 12-én született, sokgyermekes polgári családban, Nagykanizsán. Itt végzi el a középiskolát, majd a híres selmecbányai erdészeti föiskolán tanul tovább, ahol 22 évesen diplomázik. Sőt ott is helyezkedik el mint erdészjelölt. 1895-ben lesz erdész, majd állami ösztöndíjjal a karlsruhei főiskolán, illetve Baden-Ba- 


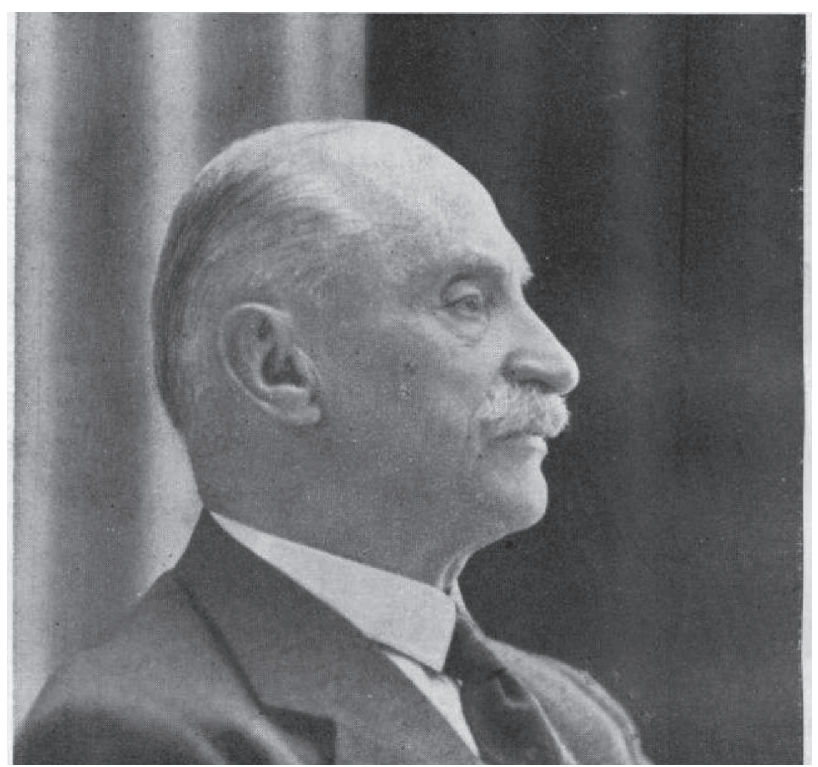

denben, a fekete-erdői erdészetben folytat további tanulmányokat. Később is igen sokfelé jár Európában, útjainak élmény- és ismeretanyaga tudományos műveinek igényes és jól átgondolt nemzetközi kitekintéseiben is rendre visszatükröződik. Az 1901-ben már főerdész, majd az erdészeti, de közgazdasági és természetvédelmi kérdésekről is egyre többet publikáló szerző - még alig túl a harmincon - már országosan ismert és elismert szakember, mai szóhasználattal élve szakíró-alkotó személyiséggé válik.

A huszadik század első évtizedének végén a minisztériumba rendelik, ahol a közismerten igényes és igen szigorú, legendásan erőskezű Kaán Károly erdötanácsos, majd erdőfőtanácsos lesz, a hihetetlen méretü és léptékủ közvagyont képező magyar állami kincstári erdők főfelügyelő kormánybiztosaként.

Különösen fontos momentumként értékelhetjük, hogy 1914-ben ő lesz hazánk első, kinevezett természetvédelemi kormánybiztosa ${ }^{10}$. Majd államtitkári rangban az erdészet felelőseként dolgozik a Károlyi-kormányban, sőt a Tanácsköztársaság idején is.

Az Országos Erdészeti Egyesület megbízásából írja egyik első fő művét, amely még általános „erdőpolitikai kérdésekkel” foglalkozik (lásd a tanulmány végén Kaán Károly válogatott bibliográfiájának 7. tételét). Ezután lesz az Alföld fásításának kezdeményezője, de mai tudásunk alapján is nyugodtan kijelenthetö, hogy ezen messze túllépve, a régió első átfogó, komplex szemléletủ és gondolatvilágú fejlesztési koncepciójának a megfogalmazója is. Végül, jogalkotói pályája csúcsán ő készíti el - e teljesítményével is messze megelőzve korát - az első természetvédelmi törvényünket. 
Közhivatalt 1924-ig visel, mint államtitkár, illetve címzetes államtitkár ${ }^{11}$, majd ugyanebben az évben a Magyar Tudományos Akadémia levelező tagja lesz. Székfoglalóját május 8-án, különös címmel - „Elváltozások az Alföld képében" - tartja ${ }^{12}$. Az 1925-ben, 58 évesen bekövetkezett hivatali nyugdíjazása után is igen aktívan dolgozik. Korábbi kutatásait rendre kibővíti, tematikájukat kiszélesíti, gondolataiban megújítja, elmélyíti. Két utolsó nagy műve (Természetvédelem és természeti emlékek Bp. 193113, Alföldi kérdések: Erdók és vizek az Alföld kérdéseiben, Bp., 1939) egészen káprázatos tárgyi tudásról és - napjaink szófordulatával élve - a térben, tájban, gazdaságban, településekben, társadalomban, azaz a „régióban” való komplex gondolkodásról tanúbizonyságot tevo", valódi tudományos szintézisnek tekinthető.

\section{Kaán Károly múveinek ma is fontos értékeirôl - általában}

Gyakran esik ma szó arról - s nyilván nem véletlenül -, hogy a különböző nagyobb tudományterületeknek az ismerethalmazai egyre bonyolultabbak, sőt nemritkán egyre áttekinthetetlenebbek még a kutatók és a fejlesztők számára is. A különböző tudáselemeket vagy egyes eredményeket tekintve gyakran igen szétaprózottnak tűnő kisebb-nagyobb munkákból állnak össze egy-egy táj vagy térség fejlesztéséhez szükséges ismeretek. A feltárt és egyre bonyolultabb kölcsönhatások alapján feltett tudományos igényủ kérdések megválaszolása érdekében az egyes szűkebb szakterületeken egyre mélyebbre hatoló, sokszor csak az adott részterületet feltáró kutatások születnek. Sőt, az esetek jelentős többségében elmarad a „szintézis”, a területi kutatási eredmények olyan átfogó összegzése, amely igyekszik az adott problémát több tudományterület eredményeinek egységes gondolatmenetbe füzésével, sőt ezen eredményeknek egy adott markáns tájban bekövetkezett hatásait is értékelve, mintegy új minőséget is alkotva, megmagyarázni. Azzal a nem titkolt komoly igénnyel, hogy tudományosan megalapozott javaslatokat tegyen a szükséges területi beavatkozásokra, változtatásokra.

A hazai regionális tudományok tekintetében Kaán Károly valóban igazi „előfutárnak” tekintheto, mert munkáinak egyre - mondhatni spirálisan - bővülő tárházában több tudomány és tudományszakág eredményeinek a tudáskészletére építkezik. Az Alföld, az ő kifejezését kölcsönözve, e „múltban nem kellően kultivált sikság" "14, csak akkor jelenthet számottevő erőforrást az ország számára, ha a „gazdasági, a kulturális és szociális helyzetének”15 problémáit, a belőlük fogalmazható "nehéz kérdések" egész sorát felvetjük, sőt azokra tervszerü megoldásokkal válaszolunk. „A legjobb megoldás egyoldalú végrehajtása ugyanis nem vezethet célhoz. Sót még jobban bogozná az ott elótérbe jutó elég bonyolult problémákat!"16

Találó fogalmazás, ami régies stílusa ellenére nagyon világosan érthető, sőt alkalmazható napjaink Alföldjére is. Ezt a mai szóhasználattal élve komplex személetű, integrált felépítésű regionális tudományi gondolatmenetet akár 
korszerünek is mondhatjuk, mert mögötte valóban alapos empirikus és a kor széles szakirodalmát jól ismerő tudós áll.

Kaán Károly munkásságának másik igen nagy értéke, hogy a munkáival a szűkebb szakterületeket művelő kollégáin és tudóstársain túl a kezdetekben ugyan még gyér létszámú, de később egyre szélesedő úgynevezett „művelt közönséghez" is szólni akar. S szól is. Az akkori, a klebelsbergi kultúr- és tudománypolitika fontos stratégiai eleme volt, hogy a falusi-tanyasi tanítótól a vidéki papokon át az orvosokig lehetőleg mindenki ismerje azokat a fontosabb és nem ritkán valóban olvasmányosan megírt tudományos ismeretterjesztő műveket, amelyek az Alföldről vagy éppen más vidékeinkről, kistájainkról szólnak. Ez a növekvő számú művelt közönség és számos lokális közösség teremtette meg és éltette jó másfélkét évtizeddel később a népi írók, szociográfusok munkásságának szellemi holdudvarát is. A tanyai iskolák és a kisfalvak olvasóköreit, a gazdaképzéseket. Egyébként e tudatos beavatkozások valóban eredményeztek „felvirágzást” az Alföld egyes mezőgazdasági - elsősorban zöldség- és gyümölcstermesztő - körzeteiben, jelentős exportbevételeket is hozva a nagy gazdasági világválságból kilábalni igyekező akkori Magyarországnak. E mozgalomnak volt egyébként az egyik szellemi vezetője egy harmadik híres kortárs, Kogutowicz Károly szegedi geográfus professzor, aki 1925-ben létrehozta az Alföldkutató Bizottságot is, elsősorban a régió fejlesztésének, szűkebb értelemben a homoki szőlő-, gyümölcs- és zöldségkultúrája megteremtésének tudományos igényű támogatására.

A komplexitás, a sokoldalú megközelítések mellett fontos értéke Kaán munkásságának a történelemszemlélete. Először is nem hagy kétséget afelől, hogy egy ekkora táj fejlesztésének „új irányba terelése” csak hosszabb folyamat lehet, amely számol az erős hagyományokkal, azokkal az adottságokkal, erőforrásokkal, amelyeket a különböző történelmi korokban különbözőképpen használt ki e táj népe. A történelemtudományból táplálkozó ismereteinek két megfellebezhetetlen főszereplője van, akiket különösen „Az alföldi probléma talpraállásunk kérdésében"17 c. munkarészben emel piedesztálra: Szent István királyunk és Gróf Széchenyi István ${ }^{18 .}$ Vizsgált régiónk szempontjából az előbbit a jól múködő és területi vonatkozásaiban is példaértékü államszervezet kialakítása, az utóbbit a Tisza szabályozására és a közlekedés fejlesztésére kidolgozott koncepciója miatt tartja megkerülhetetlennek még a XX. század első negyedében is.

Eléggé nyilvánvaló, hogy történelemszemlélete kialakításának talán legérdekesebb vonatkozása: szinte minden akkori történelmi munkát, sőt fontosabb újságcikket is elolvasott az Alföldről. Így Thessedik Sámueltől Hornyik Jánoson át Czettler Jenőig, Osváth Páltól Zoltai Lajoson át Vedres Istvánig minden mérvadó, sőt ma is gyakran citált tudományosan számba vehető szerző munkásságát jól ismeri, és mai szemmel nézve is precízen, gondosan idéz is. Forrásfeltárása nemcsak példa, de kincs is egy Alföld-kutató számára.

Nagyon érdekes az - sőt egyet is érthetünk vele -, hogy milyen markáns szerepet szán értekezéseiben az alföldi városok identitásának, hagyományainak, lokális társadalmi szervezettségének. Számtalanszor tér ki Debrecen, Szeged, Hódmezövásárhely, Kecskemét, Kisújszállás, Karcag ${ }^{19}$ stb. egy-egy fontos helyi gazdasági vagy 
éppen politikai típusú lokális fejlesztési megoldására. Alapos fejezetek szólnak több munkájában is - mintegy történelmi távlatba helyezve azokat - a tanyákról. Arról, hogy a „sivány homok” hasznosításában a mezővárosok által szorgalmazott és véghezvitt földbérleti rendszereknek milyen jelentős szerepe volt, segítve a sikeres tanyásodást, az egykori pusztaföldek frontier tipusú birtokba vételét.

De több műve számos alfejezetében foglalkozik azzal is, hogy történelmi visszatekintésre van szükség ahhoz, hogy a táj természetes vagy természetközeli arculatához „visszatérjünk”. Elemzi, hogy a török hódoltságot megelőzően és a később túllegeltetést okozó alföldi nagyállattartás előtt mennyivel sokszínűbb, gazdagabb erdős-ligetes növényzettel jellemezhető területhasználat volt tipikus az Alföldön.

Kaán Károly következő nagy tudósi-gondolkodói értékének tekinthetjük pontosságát, hitelességét, a jól kiválogatott, részletező adatokra építő elemzőképességét. Tisztában van azzal, hogy az Alföld látszatra, vagy a külső szemlélő által elképzelt „egységes” síksági táji mivolta ellenére nagyon különböző résztájegységekből, illetve az azokon élő mezővárosi és tanyai „világok” különös együtteséből áll össze. Ezért ma is példaértékű, ahogyan ezeket a statisztikai, majd gazdasági számításait és javaslatait rendre felépíti (2. ábra).

2. ábra: Kecskemét és Hódmezővásárhely birtokmegoszlása Kaán Károly statisztikája szerint

Land size distribution in Kecskemét and Hódmezóvásárhely according to Károly Kaán's statistics

\begin{tabular}{|c|c|c|c|c|c|c|c|c|c|c|c|}
\hline \multicolumn{12}{|c|}{ Kecskemẻt tjv. birtokmegoszlása az 1925. évi } \\
\hline \multirow[t]{2}{*}{$\begin{array}{l}\text { A birtoknagyságkategóriák } \\
\text { megnevezése }\end{array}$} & \multirow{2}{*}{ 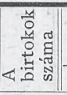 } & $\begin{array}{l}\text { Szántó- } \\
\text { föld }\end{array}$ & Kert & Rét & Szölö & Legelö & Erdö & Nádas & \begin{tabular}{|l|} 
Földado \\
alá nem \\
esố
\end{tabular} & \multicolumn{2}{|c|}{ Összes } \\
\hline & & \multicolumn{7}{|c|}{ terület kataszteri holdakban } & & & $\% / 0^{-b a n}$ \\
\hline 100 kat. holdon alul .. & 3) & 51,736 & 282 & 9,054 & $9,96 \mathrm{i}$ & 3,031 & 2,589 & 291 & 2,250 & 79,194 & 48.5 \\
\hline $100-500$ kat. holdig. & 138 & 14,053 & 107 & 3,527 & 770 & 2,288 & 1,084 & 138 & 964 & 22,931 & 14.0 \\
\hline $500-1,000$ & 8 & 1,658 & 33 & 554 & 1,028 & 865 & 108 & 93 & 394 & 4,733 & 2.9 \\
\hline $1,000-5,000$ & 1 & 384 & 3 & 186 & 3 & 316 & 5 & 14 & 156 & 1,067 & 0.7 \\
\hline $5,000-10,000$ & 1 & 2,420 & 5 & 311 & - & 1,986 & 829 & 22 & 275 & 5,848 & 3.6 \\
\hline 10,000 kat, holdon felül .. & 1 & 13,843 & 151 & 3,514 & 190 & 16,727 & 10,075 & 201 & 4,763 & 49,464 & 30.3 \\
\hline Összesen.... & & 84,094 & 581 & 17,146 & 11,952 & 25,213 & 14,690 & 759 & 8,802 & 163,237 & 100.0 \\
\hline
\end{tabular}

Hódmezôvásárhely tjv. birtokmegoszlása

XIV. tábla. az 1925. évi állapot és birtoknagyságkategóriák szerint. ${ }^{1}$ )

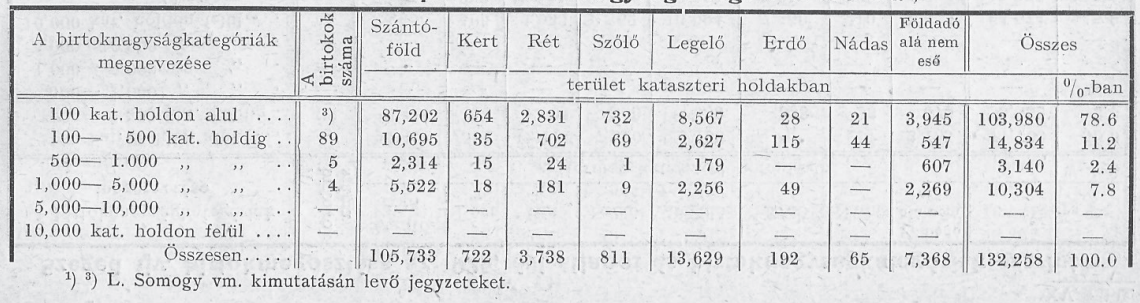

Forrás: Kaán K. 1927: A magyar Alföld: Gazdaságpolitikai tanulmány, Budapest, 1927, 225. 
Végül igen különös - de általános - értéknek tekinthetjük azt a fogalmazási stílust, amit szerzőnk képvisel. Bár szövege ma már kissé régiesnek hat, ami természetes, mégis meglepő az a gondolati tisztaság és az a hallatlanul erős tudományos textus, amellyel a régió jobb jövőjébe vetett hite alapján fogalmaz. „Az anyagiakban indult volna meg minden irányban ez a haladás, hogy ennek révén a 'szellemiekben' való megerősödését is biztositani, s mindezzel a 'magyarság kiválását' és 'felvirágozását', majd pedig önállóságát is biztositani lehessen!" - írja Szent István és Széchenyi örökségéről. Majd így folytatja: „... a múlt század második felében és jelen századunknak a világháborúig eltelt pár évében az Alföldön egynémely irányban végzett, de sajnos nem összefoglaló, egységes tervbe illesztett ${ }^{20}$ kormánytevékenység - mint láttuk - jelentékeny előnyei dacára hátrányos következményekkel is járt".

Gyakran, a feszes szakszöveg között, egészen váratlanul és mondhatni igen köznapian fogalmaz, a reformkor óta igen jellemz”, „magyaros”, önostorozó stílusban. Az itt élő emberek „az Alföldön, sárban, elhagyatottan élő magyar falusi gatyás életet” élnek. Alapvető tulajdonsága e népnek, hogy „csak akkor dolgozik, ha szükség vagy a javai gyarapitására irányuló vágya szorítja”. Idézi Széchenyit is: „Kenyere, sódara van, gatya nyáron, bunda télen, egy pár csizma és egy kalap, ólmos kézben, s néha egy szívrepesztö szomorú nóta, meg 'andalgó álom', amennyi kell - minek fölibe munka?"21

\section{Kaán Károly Alföld-fejlesztési elképzeléseinek kulcsterületei}

Elemzett szerzőnknek a legalaposabb összegző Alföld-munkája, „A MAGYAR ALFÖLD" 1927-ben jelent meg 22 . A 351 oldalas művet a Magyar Tudományos Akadémia adta ki. A kötetnek a 3. ábrán másolatban látható főbb fejezetei világosan tükrözik Kaán Károly eredeti és összetett, mai szóhasználattal - komplexnek nevezhető - gondolatmenetét. Jól érzékelhető, hogy ez a munkája is messzebb mutat, mint hogy o "csak” az Alföld fásításának az atyja lett volna. A fejezetekben azt keresi, hogy melyek azok a fejlesztési kulcsproblémák, illetve kérdések, amelyekre mindenképpen választ kell találni ahhoz, hogy e régió társadalmának sorsa jobbra fordulhasson.

A már említett - Széchenyi Istvánra részletesen hivatkozó - Tisza-szabályozási, hajózási, közlekedési stb. koncepciókra alapozva (lásd 3. ábra II. fejezet) Kaán Károlyt szinte minden tekintetben a nagy előd munkássága folytatójának tekinthetjük. Ha valaki Széchenyinek csak az Alföldet érintő munkásságára kíváncsi, szinte elegendő elolvasni Kaánnak ezt a közel harminc oldalát. Szó szerinti idézetekre és pontos hivatkozásokra építve alapozza meg saját későbbi mondanivalóját is, jelezve, hogy a legnagyobb magyar Alföld-terveinek csak töredéke valósult meg a Tisza általa kezdeményezett szabályozásával vagy a vasútépítésekkel. A talaj termőértékének megőrzése, a fásítás (pl. szederfák 
3. ábra: Kaán Károly szintetizáló Alföld-munkájának tartalomjegyzéke Contents of Károly Kaán's synthetic geographical work on the Alföld

\section{TARTALOM.}

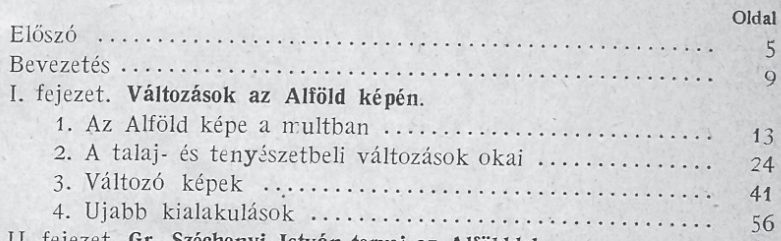

II. fejezet. Gr. Széchenyi István tervei az Alfölddel.

1. Az Alföldi magyarság boldogulásának biztositása ...... 74

2. A gazdasági és kultúrális fejlödés eddigi akadályai és jövö-

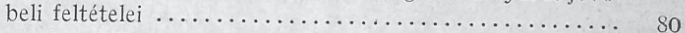

III. fejezet. A természet megzavart rendje és a gazdasági kérdések.

1. Természeti rendellenességek és azok ellenszerei ....... 98

2. Az elszikesedés gazdasági kérdései $\ldots \ldots \ldots \ldots \ldots \ldots \ldots . . \ldots \ldots$

3. Az erdö, úgy is, mint a mezögazdaság és a közegészség jelentös tényezöje

IV. fejezet. A tanya-világ.

1. A kialakulás és elözményei $\ldots \ldots \ldots \ldots \ldots \ldots \ldots \ldots \ldots 159$

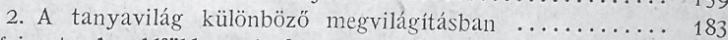

V. fejezet. Az Alföld gazdasága.

1. Földet zsaroló népszokások ................... 210

2. Gazdasági eredmények ............................ 218

3. A meg nem felelő gazdasági politika következményei ... 270

VI. fejezet. A gazdasági és kultúrális vérkeringés nehézségei.

1. Fejlödés-történelmi vázlatok ................. 289

2. A föbb vasuti hálózat kifejlődésének akadályai ........ 298

3. A helyi érdekü vasutak és azok építésének elakadása $\ldots . .303$

4. A gazdasági kisvasutak kérdése ............... 316

5. Az egészséges gazdasági és kultúrális vérkeringés feltételei 327

VII. fejezet. Az alföldi probléma talpraállásunk kérdésében ... 336

Forrás: Kaán K. 1927: A magyar Alföld: Gazdaságpolitikai tanulmány, Budapest, 1927, 225.

ültetése), a hajózható folyók és csatornák, az iparosítás mind ott szerepeltek azok között a távlati tervek között, amelyek felelevenítését Kaán Károly nemcsak aktuálisnak, de elkerülhetetlennek is ítéli. Milyen furcsa érzése támadhat az olvasónak: kétszáz éve szinte ugyanazokat a fö alföldi problémákat „görgeti maga előtt" a régió. S csak egyes részterületek tekintetében voltak sikerek. Azok is csak időleges részsikerek.

Nagyszerü gondolatok sorát olvashatjuk - szintén mai aktualitások sorát felfedezve - az alföldi természetes táj „megzavart rendjéről”. Nagy elődje ismeretanyagát jóval meghaladva értekezik Kaán több művében is az egyre szélsőségesebb klímájú Alföldön a mezőgazdasági termelés kiegyensúlyozott biztonsága végett szükségessé váló öntözésről, a lokális klímát kedvezően befolyásoló erdősítésekről, vagy éppen a talajjavítás szükségességéről, a régió talajai termőképességének elengedhetetlen fontosságú megőrzéséről. 
Általában, sőt csaknem mindig pozitív példák sorát felhozva értekezik: a szorgalmas szarvasi népról, amely 12000 hold földet javított meg, vagy éppen a karcagi földmüves iskola példaadó tevékenységéröl, ahol nemcsak termőföldet, de kaszálót, legelőt is javítottak meg mésziszappal, sőt a javított területen még sikeresen erdöt is telepitettek. ${ }^{23}$

Csaknem minden müvének minden fejezetében igen fontos szerepet tulajdonít az alföldi sajátosságoknak, úgymint a mezővárosi közösségek eltérő szokásainak, kulturális különbözőségeinek, annak, hogy az eltérő bérleti, földbérleti rendszerek mennyire egyedi megoldásokkal jellemezhető lokális szokásrendet eredményeztek.

A következő jelentős, Kaán Károly által is többször és sokféleképpen megjelenített alföldi kulcsterület természetesen a mezőgazdaság. Ma is irigyelhetően alapos statisztikai apparátusra építi okfejtéseit, s gyakorlatilag mindent adatokkal támaszt alá, indokol. Lebilincselően érdekes, ahogy táblázatai többségében másfél évtizedet (1911-1926), tehát egy hosszabb, és a megcsonkított ország újjáéledésének bizonyítékául is szolgáló időszakot vesz górcső alá. Az alföldi mezővárososok és megyék adatai mellett rendre Sopron és Somogy megye jelenik meg „kontrollpéldaként", amivel mindig hangsúlyozni kívánja a szerző az Alföld másságát, az eltérések földrajzi, történelmi, fejlettségbeli okait és részben következményeit is. Rendre beszúr efféle megjegyzéseket, például az aprójószágtartás vagy éppen a tejfeldolgozás ürügyén: „Kevés a falu és rossz a közlekedés!”24

Talán a mai olvasó számára éppen ezek a gondolati váltások lehetnek a legérdekesebbek. A tények alapos ismertetése után általában mindig megjelenik vagy magának Kaánnak, vagy valamelyik alaposan meghivatkozott szerzőnek a véleménye, az álláspontja az adott témáról.

Talán nem érdektelen ebből az egyik gyöngyszemet kiválasztani. Lyde, a londoni egyetem neves professzora írta a Budapesti Hírlap 1926. április 4-i számának 2. oldalán „Angol üzenet a magyar sajtónak” címmel következőt: „,amíg a történelmi geográfia igazolása szerint a Magyar Alföld az európai biztosság kulcsa, addig a gazdasági geográfia azt tanítja, hogy a Magyar Alföld a legpompásabb emberfajta és a legkiválóbb mezögazdák bölcsője."25

Végül Kaán Károly különösen jó érzékkel emel ki munkáiban stratégiai kérdéseket, még ha a maga korában azokat nem fejlesztési prioritásoknak vagy komplex regionális koncepcióknak hívták is.

Ezek egyértelműen: a közlekedés fejlesztése, a régióbeli mezőgazdaság eltartóképességének növelése - beleértve az erdősítések többoldalú fontosságát is -, a tanyakérdés (és a tanyaközségek megszervezése), végül a területi egyenlőtlenségek mérséklése. Kissé más stílusban, de ma is nyugodtan leírhatnók az utóbbival kapcsolatosan: „Addig sokat nem áldozhat a szegényebb szülö szépen fejlődo egyik gyermekére, amíg a másik több tekintetben a kultúra elemi fokát sem érte el, amíg azt a szellemi visszamaradottság mellett még a testi leromlás kórja is gyötri, amíg nagyobb bajok veszélye fenyegeti és ezért nem csak odaadó gondosságát, de anyagi erejét is igényli" ${ }^{26 .}$ 


\section{Zárógondolatok}

Kaán Károly minden kétséget kizáróan nagy tudós volt, és egyértelműen „regionalista”. Utóbbi - mondhatni - „kettős vonatkozásban” is. Ismerte az akkori Európa országainak főbb területi, természetvédelmi stb. terveit ${ }^{27} . \mathrm{S}$ ismerte a hazai tudományosság alföldi regionális elemzéseihez szükséges eredményeit, sőt ,a politikum minden rezdülését” is, amelyet szükségesnek ítélt az általa készített koncepcionális Alföld-szintézisbe foglalt tervek megvalósításához. Realista és idealista volt egyszerre.

Adatai, folyamatelemzései, kiinduló hipotézisei, sokoldalú példái, közülük kiemelten azok, amelyek a tervezett beavatkozások gazdasági hasznosságát bizonyítják, a realista tudós maradandó alkotásai.

Következtetései, az állami beavatkozások mértékéről és szükségességéről vallott nézetei, esetenként sajátos szociokulturális tételei ma már erősen vitathatók, bár furcsa módon nem tekinthetők teljesen idejétmúltnak.

„Eltünnek majd a sivár vidékek, és tényleg eszmei virágos kerttéé lesz az Alföld” - írja akadémiai székfoglalójának végén. Majd így folytatja: „Kifejlődhetik az érdektársulás, a termelésre szervezkedés. Kialakulhat a szövetkezés minden formája, s a kisemberek ezreinek egybefoglalt terméke a nagybirtok tömegeiként jelenhetik meg a piacon. Az így óhajtott kialakulás nemzeti munkája azonban csak akkor termi meg buján és hozza meg legszebb gyümölcseit, ha a tervszerü épitőmunkától távol marad az áldatlan politikai befolyás ${ }^{29}$, ha nem érvényesülhet az egyéni önzés és a magánrérdek".

Ugyanezek a tételek csaknem ugyanígy felvethetők 2012-ben is.

\section{Jegyzetek}

1 Kaán Károly sírjának felirata a Farkasréti temetőben.

2 Kaán Károly gyakran írja ebben a formában, nyilván nagyrabecsülése jeléül, Gróf Széchenyi István nevét. A tanulmányban a továbbiakban minden olyan eredetinek tartott szakkifejezést, amelyet Kaán Károly írásaiból vettem át, dőlt betű jelez majd.

3 Kaán Károly kifejezése, melyet „Az Alföld problémája” c. munkájában használ.

4 Forrás: http://nyitottegyetem.phil-inst.hu/lit/forrad.htm. In: Szegedy-Maszák Mihály: Kemény Zsigmond két röpirata a forradalomról, Folytonosság és megszakítottság

5 Kaán Károly kifejezése, melyet „Az Alföld problémája” c. munkájában használ.

6 Szintén Kaán használja ugyanott.

7 Lásd uo.

8 Forrás: http://www.fsz.bme.hu/mtsz/mhk/csarnok/k/kaan.htm (2012. április 17.)

9 Forrás: Erdészeti Lapok digitalizált változata.

10 Az e tárgyban született "Természetvédelem és a természeti emlékek”, Budapest, $1931 \mathrm{c}$. hihetetlenül gazdagon illusztrált munkája digitalizált változatban is fellelhető a http://mek.oszk.hu/08200/08276/pdf/termeszet4.pdf címen.

11 Sírján, a Farkasréti temetőben ny. földművelésügyi államtitkár szerepel.

12 Forrás: A Magyar Tudományos Akadémia tagjai, II. kötet, MTA Társadalomkutató Központ, Tudománytár, Bp. 2003., 615-616. A szócikket írta: Markó László. 
13 Ez a műve digitális formában a Magyar Elektronikus Könyvtárban is elérhető, ahol a szerzőnek az akkori Magyarország legszebb fáiról készült katalógusa, azok leírásai és fényképei is megcsodálhatók, lásd: http://mek.oszk.hu/08200/08276/pdf/index.html (2012. április 17.)

14 In: Kaán Károly: A magyar Alföld, gazdaságpolitikai tanulmány, MTA, 1927. Előszó.

15 Lásd uo.

16 Lásd uo.

17 A Magyar Alföld, Gazdaságpolitikai tanulmány, Bp. 1927., 336-351.

18 Nem kihagyva még könyvéből azt a fontos lábjegyzetet sem, hogy Széchenyi István „édesatyja”, Gróf Széchényi Ferenc fordíttatta le magyar nyelvre 1786-ban Thessedik Sámuel 1784-ben németül megjelent művét: „A paraszt ember Magyarországban micsoda és mi lehetne."

19 „Karcag felosztja és örök tulajdonba engedi át 30000 kat. hold legelőjét a város polgárainak” In: uo., 285. old.

20 Az állóbetűs részek e cikk szerzőjének a kiemelései.

21 A Magyar Alföld, Gazdaságpolitikai tanulmány, Bp. 1927., 83 o.

22 A későbbi kiadás, lásd a válogatott bibliográfia 15. tételét, véleményem szerint már nem olyan sikeres.

23 A karcagi gazdasági iskola vezetőjének, Szentannay Sámuelnek még a „Jövedelmezo gazdálkodás szik talajon" c. kéziratos tanulmányát is meghivatkozza Kaán Károly, ami alapján pontos számításokat is közöl, hogy mi mennyibe kerül.

24 In: Kaán Károly: A magyar Alföld, 249. old.

25 Uo., 288. old.

26 Uo., 348-349. old.

27 Elég egy pillantást vetni a 12. sz. bibliográfiai tétel egyik fejezetcímére. Társadalmi tevékenység a természetvédelem szolgálatában (Poroszországban, Bajorországban, Szászországban, Ausztriában, Angolországban, Franciaországban, Olaszországban, Dániában, Norvégiában, Svédországban, Hollandiában, Svájcban, Magyarországon).

28 Nagyon jó kifejezés!

29 Kiemelés e cikk szerzőjétől.

30 Forrás: A Magyar Tudományos Akadémia tagjai, II. kötet, MTA Társadalomkutató Központ, Tudománytár, Bp. 2003, 615-616. A szócikket írta: Markó László.

\section{Kaán Károly fontosabb múvei ${ }^{30}$}

1. Nemzeti akció és erdőgazdaság. Erdészeti Lapok, 1902, 4.

2. Külföldi erdőgazdaságok faértékesitő eljárásai. Budapest, 1904

3. A természeti emlékek fenntartása. Budapest, 1909

4. Erdőgazdasági eredmények és azok gazdaságpolitikai következései. Erdészeti Lapok, 1911, 1.

5. A természetvédelem és a természeti emlékek fenntartásának kérdéseihez. Budapest, 1914

6. Erdőt az Alföldre! In: Köztelek 1920

7. Erdögazdaság-politikai kérdések. Budapest, 1920

8. Erdögazdasági problémák és azok megoldása. Budapest, 1923

9. A magyar Alföld: Gazdaságpolitikai tanulmány. Budapest, 1927

10. A Magyar Tudományos Akadémia és az erdőgazdasági tudományok. Budapest, 1928

11. Az Alföld problémája. Pécs, 1929

12. Természetvédelem és a természeti emlékek. Budapest, 1931

13. Települések és telepitések. Budapest, 1933

14. Gazdaságpolitikai feladatok. Budapest, 1936

15. Alföldi kérdések: Erdők és vizek az Alföld kérdéseiben. Budapest, 1939 